\title{
PASYJNE FENOMENY MISTYCZNE
}

\section{Wstęp}

Bezspornym wydaje się być fakt, występowania w doświadczeniu świętych Kościoła zjawisk nadprzyrodzonych ${ }^{1}$. Teolodzy wskazują, że niektóre spośród nich, zachowując charakter prywatny, wewnętrzny, znane są jedynie tej duszy, której Bóg udzielił ich w formie widzeń umysłowych, wyobrażeniowych i umysłowych słów nadprzyrodzonych ${ }^{2}$. Oddzielną grupę fenomenów mistycznych tworzą charyzmaty Ducha Świętego „uwidoczniane na zewnątrz i obserwowane przez ludzi mających kontakt z osobami, które noszą tego znaki lub dają im w jakiś sposób wyraz"’3. Są wśród nich m.in. aureola, wznoszenie się do góry, stany ekstatyczne, równoczesne przebywanie $\mathrm{w}$ dwóch odległych miejscach, promieniowanie świetlne, promieniowanie wonne, długie wstrzymywanie się od pokarmu także od snu, stygmatyzacja, dar łez ${ }^{4}$; charyzmat wiary - czynienie cudów, czuwania czyli bezsenności, czytanie w sercach, fenomeny słuchowe, głosy zewnętrzne i wewnętrzne, mówienie językami; nadzwyczajna ciężkość, niebiańska muzyka, niepalność, niewidzialność, niewysłowioność; objawienia, odróżnianie świętych lub poświęconych przedmiotów, omdlenia; pocenie się krwią, pożar miłości, prorokowanie, przebicie serca, przemienienie, przenoszenie ciała w przestrzeni, rana miłości, rozkoszowanie się Bogiem; przesuwanie się przedmiotów, spoczynek w Duchu Świętym, subtelność, ukazywanie się istot pozaziemskich; ukoronowanie cierniem,

1 U. Occhalini, Przedmowa, w: Chrześcijańskie fenomeny mistyczne. Stownik, Kielce 2018, s. 10 .

2 A. Tanquerey, Zarys teologii ascetycznej $i$ mistycznej, Warszawa 2003, t. 2, s. 511-513; U. Occhalini, Przedmowa..., dz. cyt., s. 10; R. Talmelli, Lokucje, w: Chrześcijańskiefenomeny mistyczne. Słownik, Kielce 2018, s. 47-49; S. Urbański, Teologia życia mistycznego, Warszawa 1999, s. 336-354. R. Garrigou-Lagrange, Trzy okresy życia wewnętrznego, Niepokalanów 2001, s. 866-867, 869; S. Witek, Teologia życia wewnętrznego, Lublin 1986, 455-456; L. Borriello, Słowa sukcesywne, w: Chrześcijańskie fenomeny mistyczne. Słownik, Kielce 2018, s. 114-116.

3 U. Occhalini, Przedmowa..., dz. cyt. s. 10.

4 J. Gogola, Fenomeny doświadczeń mistycznych, w: Encyklopedia Katolicka KUL, t. 12, Lublin 2008, 1292-1293; A. Tanquerey, Zarys teologii..., dz. cyt., s. 525-531; S. Urbański, Teologia życia..., dz. cyt., s. 337; R. Garrigou-Lagrange, Trzy okresy..., dz. cyt., s. 875, 879; S. Witek, Teologia życia..., dz. cyt., 455-456. 
woń duchowa, przepowiadanie przyszłych wydarzeń, wydłużenie ciała, zamiana serca, zaślubiny mistyczne ${ }^{5}$.

W niniejszym artykule, korzystając z badań katolickich teologów, zostanie podjęta próba opisu tych fenomenów mistycznych, które wiążą się ściśle z Misterium Męki Jezusa Chrystusa. Najpierw omówione będę dwa zjawiska ukryte przed światem zewnętrznym, które znane są samemu mistykowi. Są nimi transwerberacja i niewidzialne stygmaty. W drugiej kolejności zostanie poddany analizie charyzmat stygmatów widzialnych, wyrażający się w formie żywych ran odpowiadających miejscom zranień Jezusa Chrystusa, oraz zjawiska pochodne w stosunku do stygmatów żywych: ubiczowania, ukoronowania cierniem, krwawego potu i mistycznie namalowanych obrazów ${ }^{6}$. Po omówieniu każdego z wymienionych zjawisk mistycznych, podane zostaną przykłady aplikacji tychże $\mathrm{w}$ doświadczeniach religijnych wybranych mistyków Kościoła. Są wśród nich: św. Franciszek z Asyżu (1181-1226) św. Teresa z Avila (15151582), św. Weronica Giuliani (1660-1727), Anna Katarzyna Emmerlich (1774-1824), Gemma (1878-1903) św. Siostra Faustyna Kowalska (1905-1938), Luiza Picarreta (1865-1947), bł. Helena Aiello (1895-1961), Teresa Neumann (1898-1962), św. Ojciec Pio z Pietrelciny (1887-1968), Natuzza Etolo (1924-2009)7.

\section{Mistyczne przebicie serca (transwerberacja)}

R. Di Muro wyjaśniając pojęcie transwerberacji stwierdza, że „termin ten oznacza przebicie epidermy i przeniknięcie zaostrzonego przedmiotu - strzały, grotu, włóczni - do serca, dokonane przez samego Boga lub przez niebiańską istotę typu anielskiego"8. Jego zdaniem doświadczenie to wywołuje ogromny ból w piersiach i pojawienie się znaków w boku. Ból może mieć charakter moralny, a czasem i fizyczny. W niektórych przypadkach mistyk cierpi i duchowo i cieleśnie?

R. Di Muro, podejmując zagadnienie mistycznego przebicia serca, wskazuje m.in. na św. Teresę z Avila i św. Ojca Pio jako na mistyków, których Bóg wyróżnił tym nadzwyczajnym przywilejem. Natomiast W. Rachwalik wskazał współczesną polską mistyczkę Alicję Lenczewską, jako na również wyróżnioną tym mistycznym fenomenem.

Chrześcijańskie fenomeny..., dz. cyt., s. 24-26, 45, 47, 52, 54-55, 57, 60, 62-63, 70, 7273, 80, 84-85, 92, 95, 98-99, 108, 111, 116, 125, 133-134, 142, 144, 147.

6 K. Turowski, Oblubienica Boga, rozmowa z ks. Walterem Rachwalikiem ojcem duchownym Alicji Lenczewskiej, Kraków 2019, s. 19.

7 W 2016 r. zaistniała w świadomości Kościoła polska mistyczka Alicja Lenczewska (19342012), autorka książek Świadectwo i Słowo pouczenia; z jej pism wynika, że doświadczała licznych darów mistycznych, także związanych z Męką Zbawiciela: W. Rachwalik, Pisma Alicji Lenczewskiej jako przykład literatury z zakresu mistyki, „Świdnickie Studia Teologiczne" 15 (2018), nr 1, s. 157. Z uwagi na fakt trwających nad jej pismami mistycznymi badań, w tym artykule ograniczamy się jedynie do krótkiej o niej informacji.

8 R. Di Muro, Przebicie serca (transwerberacja), w: Chrześcijańskie fenomeny mistyczne. Słownik, Kielce 2018, s. 95.

9 R. Di Muro, Przebicie serca..., dz. cyt., s. 95. 
L. Borriello analizując mistyczne doświadczenia św. Teresy z Avila, przywołał sporządzony przez nią opis okoliczności transwerberacji jej duszy. W pewnej chwili, jak czytamy w jej notatce, Teresie ukazał się anioł, który „nie był wysokiego wzrostu, raczej mały, a bardzo piękny. $Z$ twarzy jego płonącej niebieskim zapałem znać było, że należy do najwyższego rzędu aniołów, całkiem jakby w ogień przemienionych. (...) Ujrzałam w ręku tego anioła długą złotą włócznię, a grot jej żelazny u samego końca był jakby z ognia. Tą włócznią kilka razy przebijał moje serce, zagłębiając ją aż do wnętrzności. Za każdym wyciągnięciem włóczni miałam to uczucie, jakby wraz z nią wnętrzności mi wyciągał. Tak mnie pozostawił, całą gorejącą wielkim zapałem miłości Bożej. Tak wielki był ból tego przebicia, że wyrywał mi z piersi (...) jęki (...). Ale taką zarazem przewyższającą wszelki wyraz słodycz sprawia mi to niewypowiedziane męczeństwo, że najmniejszego nie czuję w sobie pragnienia, by ono się skończyło i w niczym innym dusza moja nie znajduje zadowolenia, tylko w samym Bogu. Nie jest to ból cielesny, ale duchowy, chociaż i ciało niejako, owszem, nawet znaczny ma w nim udział. Taka mu towarzyszy słodka między Bogiem a duszą wymiana oznak miłości, że opisać jej nie zdołam, tylko Boga proszę, aby w dobroci swojej dał zakosztować jej każdemu, kto by mnie nie uwierzył. Ile razy miałam to widzenie, chodziłam cały dzień jak nieprzytomna. Nie chciało mi się na nic patrzeć ani z nikim mówić, a tylko rozkoszować się swoją męką, którą uznawałam sobie za chwałę większą nad wszystko, cokolwiek było chwałą i wielkością w całym stworzeniu" ${ }^{\prime}$.

L. Peroni stwierdza, że św. Ojciec Pio otrzymał łaskę transwerberacji 5 sierpnia 1918 r. ${ }^{11} \mathrm{~W}$ liście skierowanym 21 sierpnia 1918 r. do kierownika duchowego o. Benedetto, św. Ojciec Pio poinformował go o zaistniałym w pierwszych dniach sierpnia mistycznym zdarzeniu: „Spowiadałem właśnie naszych chłopców piątego wieczorem, kiedy nagle wypełniło mnie przerażenie na widok niebiańskiej istoty, która ukazała się mojej duszy. W ręku trzymała ona jakieś narzędzie, podobne do najdłuższej, żelaznej włóczni z dobrze zaostrzonym końcem, z którego jak się wydawało, buchał ogień. Patrzenie na to wszystko i doświadczenie, jak ta postać wbija $\mathrm{z}$ całą gwałtownością narzędzie w moją duszę, było jednym i tym samym. $\mathrm{Z}$ trudem krzyknąłem z bólu, czułem, że umieram. Powiedziałem chłopcu, żeby odszedł, gdyż czułem się źle i nie miałem już sił, aby kontynuować spowiedź. To męczeństwo trwało bez przerwy aż do poranka siódmego dnia sierpnia. Tego, jak bardzo cierpiałem w tym bolesnym okresie, nie umiem opisać. Widziałem nawet swoje wnętrzności wydzierane przez to narzędzie i wszystkie wydane na pastwę żelaza i ognia. Tego dnia zostałem śmiertelnie zraniony. W najgłębszej części mojej duszy czuję ranę, która będąc zawsze otwarta, sprawia, że doznaję nieustannych katuszy"12.

${ }^{10}$ L. Brriello, Teresa z Avila i transwerberacja, w: Chrześcijańskie fenomeny mistyczne. Stownik, Kielce 2018, s. 167.

11 L. Peroni, Ojciec Pio. Petna biografia w 40. rocznicę śmierci, Kraków 2008, t. 2, s. 283 ns.

12 Tamże. Daru przebicia serca Bóg udzielił również Alicji Lenczewskiej, o czym wspomniała w dzienniku duchowym pod datą 3 maja 1987 r.: „Był nietypowy ból w boku, w okolicach serca. Wielokrotne ukłucie jakby z zewnątrz”. A. Lenczewska, Świadectwo, Poznań 2016, s. 351. 


\section{Stygmaty niewidzialne}

Wśród łask udzielanych przez Boga duszom wybranym, ważne miejsce przypisuje się charyzmatycznym niewidzialnym stygmatom. Najczęściej są udzielane podczas zjawisk ekstatycznych o czym świadczą zachowane na piśmie zeznania wybranych mistyków: Luizy Picarreti, św. Ojca Pio, św. Siostry Faustyny Kowalskiej.

Jak podaje M. R. Del Geno, w 1894 lub 1895 r., Luiza Picarreta, włoska mistyczka, podczas jednej z licznych ekstaz, w Święto Podwyższenia Krzyża, znalazła się w Jerozolimie, gdzie w miejscach męki Jezusa Chrystusa przeżyła „zaślubiny mistyczne krzyża” ${ }^{13}$. Podczas zaślubin otrzymała stygmaty, ,które jednak na jej zdecydowaną prośbę pozostały niewidzialne"14. W tej samej chwili Bóg udzielił jej daru poznania własnej grzeszności, co rodziło w jej duszy wielkie cierpienia ${ }^{15}$.

I. Burchacka podaje istotną wzmiankę związaną z Ojcem Pio. Otóż po przyjęciu dnia 10 sierpnia 1910 r. święceń kapłańskich, ze względów zdrowotnych zamieszkał on w Pietrelcinie. Wkrótce potem, dokładnie dnia 7 września, Ojciec modlił się w swojej małej pustelni, którą zbudował na polu swoich rodziców, na Piana Romana. W tej samej chwili ukazali mu się Chrystus i Matka Najświętsza i otrzymał stygmaty. Zdumiony udał się do proboszcza. Pokazując stygmaty, poprosił: „Wujku Tore, błagam, prośmy Chrystusa, by uwolnił mnie od tego znaku. Pragnę cierpieć, umrzeć z cierpienia, ale żeby to było w ukryciu"16. 8 września następnego roku Ojciec wysłał list do kierownika duchowego, z którego wynika, przez cały mijający rok dotkliwie odczuwał bóle $\mathrm{w}$ dłoniach i w stopach ${ }^{17}$. Aż do 20 września $1918 \mathrm{r}$. Ojciec cierpiał w tajemnicy przed światem, w znaku niewidzialnych stygmatów ${ }^{18}$. Gdy otrzymał stygmaty widzialne, oznajmił tym, którzy je zobaczyli: „Wy widzicie je teraz, ja widziałem je już w 1910 roku"19.

W. Rebeta, badając tajemnice cierpień, które za życia znosiła św. Siostra Faustyna Kowalska stwierdził, że wśród nich „,doświadczyła przeżyć o nadzwyczajnym charakterze, których specyfika pozwala na zakwalifikowanie ich do typu cierpień stygmatycznych"20. Następnie przywołuje relację Siostry Faustyny, w której opisała okoliczności otrzymania stygmatów niewidzialnych. W Dzienniczku polskiej mistyczki czytamy: „(...) po ślubach rocznych, (...) w czasie modlitwy ujrzałam wielką jasność, a z tej jasności wyszły promienie, które mnie ogarnęły, i wtem uczułam

${ }_{13}$ M. R. Del Genio, Luiza Piccarreta, w: Chrześcijańskie fenomeny mistyczne. Słownik, Kielce 2018, s. 174.

14 M. R. Del Genio, Luiza Piccarreta..., dz. cyt., s. 174.

15 M. R. Del Genio, Luiza Piccarreta..., dz. cyt., s. 174

${ }^{16}$ I. Burchacka, Ojciec Pio. Osobowość i posługa $w$ relacjach współczesnych, Warszawa 1988, s. 11.

17 I. Burchacka, Ojciec Pio..., dz. cyt., s. 11.

18 I. Burchacka, Ojciec Pio..., dz. cyt., s. 11.

19 I. Burchacka, Ojciec Pio..., dz. cyt., s. 11.

20 W. Rebeta, Misterium cierpienia świętej Faustyny, Lublin 2014, s. 132. 
straszny ból w rękach, nogach i boku, i ciernie korony cierniowej"21. Niewidzialnych cierpień stygmatycznych Faustyna doświadczała wielokrotnie, m.in. przy spotkaniach $\mathrm{z}$ osobami będącymi w stanie grzechu śmiertelnego ${ }^{22}$. W innych przypadkach otrzymywała cierpienia ran Zbawiciela jako ekspijację za grzechy konkretnych osób $^{23}$. Z jej zapisków wynika, iż Bóg dopuszczał na nią stygmatyczną torturę podczas Mszy Świętej24, gdy odprawiała adorację Najświętszego Sakramentu ${ }^{25}$, lub gdy przebywała $\mathrm{w}$ szpitalu ${ }^{26}$. Zdarzało się, że odczuwała rany Pana w okresie Wielkiego Postu $^{27}$.

\section{Mistyczne ubiczowanie}

M. R. Del Geno, wyjaśniając zjawisko fenomenu mistycznego udziału w biczowaniu Chrystusa, najpierw przypomniał, w jaki sposób odbywało się faktyczne biczowanie. Tortura ta polegała na ,zadaniu trzydziestu dziewięciu uderzeń biczem w plecy skazanego, który otrzymywał je, mając ręce przywiązane do kolumny na wysokości około jednego metra i wystawiając grzbiet biczującym. Bicz składał się z drewnianej rękojeści i dwóch skórzanych rzemieni z ostrymi końcówkami z metalu lub kości, powodującymi rozszarpywanie ciała"28. Jego zdaniem, Bóg udziela niektórym mistykom łaski współudziału w biczowaniu Zbawiciela. Część z nich doświadcza cierpień biczowanego Pana Jezusa na sposób wewnętrzny, duchowy. Inni zostali wybrani do udziału bardziej intensywnego, doświadczając również widzialnych oznak biczowania" ${ }^{29}$. W niektórych przypadkach Bóg udziela duszy podczas tych cierpień łaski doskonałego zjednoczenia ze Swoim Synem, ,aż po utożsamienie się z Nim fizycznie"30.

Zanim pojawili się w Kościele mistycy, którym Bóg udzielił łaski doświadczania tortury biczowania Jezusa Chrystusa, najpierw świadkowie Zmartwychwstałego skazywani byli na rzeczywiste biczowanie. W Dziejach Apostolskich znajdujemy

21 F. Kowalska, Dzienniczek, Kraków 2001 [dalej: Dz], nr 759.

${ }^{22} \mathrm{Dz}$, nr 759. M. Piotrowski, odwołując się do dziennika duchowego mistyczki Alicji Lenczewskiej, stwierdza, że ona również otrzymała charyzmat niewidzialnych stygmatów: M. Piotrowski, Świadek Zmartwychwstałego - Alicja Lenczewska (1934-2012), w: Świadectwo, Poznań 2016, s. 12; W. Rachwalik, badając jej pisma stwierdził, że odczuwała ona fizycznie niewidoczne na zewnątrz cierpienia rany Jezusa Chrystusa w dłoniach, oddzielnie w sercu, czasem wszystkie równocześnie: W. Rachwalik, Pisma Alicji Lenczewskiej..., art. cyt., s. 157.

Dz, nr 348-349, 1468.

24 Dz, nr 931, 942, 964-965, 976.

25 Dz, nr 614.

26 Dz, nr 808.

27 Dz, nr 203.

28 M. R. Del Geno, Biczowanie, w: Chrześcijańskie fenomeny mistyczne. Słownik, Kielce 2018, s. 17.

${ }^{29}$ M. R. Del Geno, Biczowanie..., dz. cyt., s. 17.

30 M. R. Del Geno, Biczowanie..., dz. cyt., s. 18. 
opisy takich wydarzeń. W pierwszym przypadku rzecz dotyczyła Apostołów Piotra i Jana. Zostali skazani na ubiczowanie w Jerozolimie przez Sanhedryn, ponieważ rozpowszechniali wśród wiernych naukę o zmartwychwstaniu Jezusa Chrystusa. Kapłani żydowscy, jak czytamy, „kazali ich ubiczować” (Dz, 5,40). Podobny los spotkał w Filipii Apostołów Pawła i Sylasa. Tam, podczas zamieszek wywołanych przez Żydów, rzymscy pretorzy „kazali zedrzeć z nich szaty i siec ich rózgami” (Dz 16,22). Potem zostali wtrąceni do więzienia, z którego zostali uwolnieniu przez Boga. Jeszcze tej samej nocy strażnik więzienia zaprowadził ich do swojego domu, gdzie, jak czytamy, „obmył [im] rany” (Dz 16,33).

Włoski teolog M. R. Del Genio oświadczył, odwołując się do przeprowadzonych badań, że Bóg udzielił charyzmatu mistycznego udziału w torturze biczowania m.in. św. Weronice Giuliani (1660-1727), Annie Katarzynie Emmerlich (1774-1824), św. Gemmie Galgani (1878-1903), Teresie Neuman (1898-1962) i św. Ojcu Pio ${ }^{31}$.

\section{Stygmaty widzialne}

Zdaniem R. Garrigou-Lagrange Bóg udzielając wybranym duszom łask nadzwyczajnych, ma w Swoim zamiarze przyciągnięcie uwagi wiernych do wielkich tajemnic wiary. Wśród tych nadprzyrodzonych darów, spełniającym wspomniane zadanie, autor umieścił również stygmatyzację widzialną i niewidzialną ${ }^{32}$.

Natomiast zdaniem P. M. Marianeschi'ego z punktu widzenia medycznego stygmaty można określić ,jako obrażenia skórne lub znaki krwi o różnym kształcie, różnej głębokości i różnym umiejscowieniu, krwawiące z różną intensywnością i częstotliwością" 33 .

Zdaniem L. Peroni'ego stygmatyzacja jest specjalną łaską, „którą Bóg, znacząc dłonie, stopy i klatkę piersiową, a czasami również plecy i głowę, obdarza osoby wybrane ranami Chrystusa. Dusza wybrańca staje się w ten sposób odbiciem duszy Chrystusa i doznaje, tak jak i On, przerażających cierpień. Stygmatyk, stając się żywym obrazem Jezusa, jest powołany do kontynuowania misji zbawienia świata w swoim ciele, dopełniając braki w Jego cierpieniach"(por. Kol 1,24) ${ }^{34}$.

A. Tanquerey umieścił stygmatyzację wśród zjawisk psychofizjologicznych ${ }^{35}$. Jego zdaniem ,zjawisko to polega na pewnego rodzaju wyciśnięciu świętych ran Zbawiciela na stopach, rękach, na boku i na czole. Rany te pojawiają się samorzutnie, nie wywołane żadnym zewnętrznym skaleczeniem, i od czasu do czasu płynie z nich krew w stanie niezepsutym"36.

31 M. R. Del Geno, Biczowanie..., dz. cyt., s. 17.

32 R. Garrigou-Lagrange, Trzy okresy..., dz. cyt., s. 860, 878.

33 P. M. Marianeschi, Stygmaty, w: Chrześcijańskie fenomeny mistyczne. Stownik, Kielce 2018, s. 120 ns.

34 L. Peroni, Ojciec Pio..., dz. cyt., s. 275.

35 A. Tanquerey, Zarys teologii..., dz. cyt., s. 525.

36 A. Tanquerey, Zarys teologii..., dz. cyt., s. 528. 
Również S. Urbański charyzmat stygmatów widzialnych zaliczył do nadzwyczajnych zjawisk psychofizycznych ${ }^{37}$ : „Słowo to pochodzi od greckiego wyrazu „sigma” oznaczającego piętno, znamię, bliznę, we właściwym znaczeniu określa ono odbicie ran Chrystusowych. Jest to więc uczestnictwo w męce Jezusa, polegające na otrzymaniu krwawiących blizn i odczuwaniu fizycznego bólu, podobnych do tych, których doznawał Zbawiciel podczas swojej bolesnej męki" ${ }^{38}$. S. Urbanowicz, za ks. Puchalikiem ,podkreśla rozmaitość stygmatów, czasu i sposobu ich pojawienia się. Występują one w formie zewnętrznej przez krótszy lub dłuższy czas, niekiedy okresowo. Nie u każdej stygmatyzowanej osoby znaki są jednakowe i w tej samej liczbie. Zróżnicowanie dotyczy także kształtu, wielkości, głębokości oraz miejsca ran”39. Rany stygmatyczne „znajdują się (...) na ogół na powierzchni ciała, z dala od wielkich naczyń krwionośnych, a jednak płynął z nich strumienie krwi, zwłaszcza w pierwszym dniu"40.

Zdaniem P. M. Marianeschi'ego ,stygmatyzacja pojawia się tylko u osób miewających ekstazy, i że poprzedzają ją i towarzyszą jej bardzo silne cierpienia fizyczne i moralne, które tym sposobem daną osobę czynią podobną do Jezusa cierpiącego"41. Jego zdaniem w charyzmacie stygmatów widzialnych zostają odtworzone poszczególne etapy Męki Zbawiciela. Są wśród nich: „krwawy pot (por. Łk 22,44), rany powstałe na skutek ukoronowania cierniem i biczowania (por. Mk 15,17; J 19,1), obrażenia spowodowane uderzeniami, ciężarem krzyża i upadkami podczas wchodzenia na Kalwarię (por. Mt 26,67; Mk 14,65; J 18,22), przerwanie ciągłości tkanki skórnej i mięśniowo-ścięgnowej umieszczone na dłoniach (rozumianych anatomicznie jako nadgarstek, śródręcze i palce) i stopach, powstałe wskutek prawdziwego ukrzyżowania przy użyciu gwoździ stolarskich, szeroka rana otwarta u podstawy klatki piersiowej, wywołana włócznią jednego z żołnierzy przybyłych celem stwierdzenia zgonu" (por. J 19,33-34) ${ }^{42}$.

Teologowie wskazują na ściśle określone kryteria, według których należy ocenić nadprzyrodzone pochodzenie stygmatów. R. Garrigou-Lagrange, podejmując zagadnienie sposobu oceny stanów stygmatycznych, odwołał się do artykułu jezuity, o. L. Sempe, z roku 1937. Zdaniem O. Sempe „(...) Stygmaty prawdziwe, te które mieli święci, jedyne, które Kościół bierze pod uwagę, nie są w swojej istocie takimi ranami, jak inne. Prócz tego, są one zawsze położone w tych samych punktach ciała, co u Chrystusa i osiągają czasem te same rozmiary, jak u Niego, mają one jednak właściwości, które odróżniają je istotnie, jak sądzimy, od zwykłych ran"43.

37 S. Urbański, Nadzwyczajne zjawiska psychofizyczne, stygmaty, w: Chrześcijańskie fenomeny mistyczne. Stownik, Kielce 2018, s. 355.

38 S. Urbański, Nadzwyczajne zjawiska..., dz. cyt., s. 355.

39 S. Urbański, Nadzwyczajne zjawiska..., dz. cyt., s. 356.

40 S. Urbański, Nadzwyczajne zjawiska..., dz. cyt., s. 357.

41 P. M. Marianeschi, Stygmaty..., dz. cyt., s. 120 ns.

42 P. M. Marianeschi, Stygmaty..., dz. cyt., s. 120 ns.

${ }^{43}$ R. Garrigou-Lagrange, Trzy okresy..., dz. cyt., s. 876. 
Rany te „są (...) równie oporne wobec wszelkiego leczenia, jak niedostępne zakażeniom; żaden opatrunek ich nie leczy, a nigdy nie ropieją, choć często są otwarte i przez lata całe wystawione na działanie powietrza" ${ }^{4}$. Opisywane rany „zabliźniają się czasem w sposób nagły i doskonały, do tego stopnia, że tkanka blizny jest równie elastyczna i mocna, jak skóra z nią sąsiadująca, równie sprężysta i odporna jak tamta na uszczypnięcie lub na skręcenie, choćby poza tym pozwalała ustalić kształt i rozmiary rany będącej pod nią...." ${ }^{45}$. Ponadto „prawdziwe stygmaty krwawią okresowo w zależności od świąt liturgicznych Chrystusa i Maryi Panny. Zdarza się to też w pewne święta pozaokresowe, nieoczekiwanie dla mającej je osoby, która nie wiedziała, że wtedy te święta przypadają" ${ }^{\prime 4}$. O. Sempe przedstawił spostrzeżenie badających zjawiska stygmatyczne, ,że gdy osoba stygmatyzowana leży na wznak, krew spływa z ran nóg tak, jak spływała z ran Chrystusa, a więc w kierunku przeciwnym do siły ciążenia" ${ }^{47}$. Następie, nawiązując do krwotoków stygmatycznych, autor artykuł stwierdził, że „stygmaty są na ogół na powierzchni, z dala od wielkich naczyń krwionośnych" ${ }^{48}$, a ,jednak płynął z nich strumienie krwi”"49. Ponadto zdaniem o. Sempe, stygmaty otrzymują zwykle wierni praktykujący „,noty najbardziej heroiczne" 50 i mający szczególne nabożeństwo do krzyża ${ }^{51}$. Jego zdaniem „stygmatycy wchodzą w głębiny tajemnicy Odkupienia, w sekret cierpień duchowych i fizycznych Chrystusa, czyli Jego ofiarowania się dla zbawienia grzeszników"52. Jego zdaniem, Zbawiciel chcąc przypomnieć ludziom swoją Mękę „wybiera sobie ofiary, które w ten sposób czasem upodabnia widocznie lub niewidocznie do swego ukrzyżowania" ${ }^{53}$.

A. Teanquerey podaje znaki, po których można rozpoznać prawdziwe stygmaty: „stygmaty pojawiają się wyłącznie w tych samych miejscach, w których Chrystus Pan pięć ran otrzymał, odnawianie się ran i boleści u stygmatyzowanych dokonuje się na ogół w dniach lub w czasach, przypominających wspomnienie męki Zbawiciela, jak np. w piątki lub w jakieś święto Chrystusa Pana. Rany te nie ropieją, krew płynąca jest czysta, podczas gdy najmniejsze zranienia na ciele w innym miejscu wywołuje ropienie, nawet u stygmatyzowanych. Rany te nie goją się, mimo stosowania zwykłych środków, i trwają niekiedy lat trzydzieści i czterdzieści, sprowadzając obfite krwotoki; jest to zrozumiałe w pierwszym dniu ich pojawienia, lecz staje się niewythumaczalne w dniach następnych. Obfitości krwotoków również wytłu-

\footnotetext{
44 R. Garrigou-Lagrange, Trzy okresy..., dz. cyt., s. 876 ns.

45 R. Garrigou-Lagrange, Trzy okresy..., dz. cyt., s. 877.

46 R. Garrigou-Lagrange, Trzy okresy..., dz. cyt., s. 877.

47 R. Garrigou-Lagrange, Trzy okresy..., dz. cyt., s. 877.

48 R. Garrigou-Lagrange, Trzy okresy..., dz. cyt., s. 877.

49 R. Garrigou-Lagrange, Trzy okresy..., dz. cyt., s. 877.

50 R. Garrigou-Lagrange, Trzy okresy..., dz. cyt., s. 877.

51 R. Garrigou-Lagrange, Trzy okresy..., dz. cyt., s. 877.

52 R. Garrigou-Lagrange, Trzy okresy..., dz. cyt., s. 877.

53 R. Garrigou-Lagrange, Trzy okresy..., dz. cyt., s. 877.
} 
maczyć nie podobna; stygmaty pojawiają się zazwyczaj na powierzchni, z dala od wielkich naczyń krwionośnych, a jednak krew obficie z nich się sączy! - na koniec i przede wszystkim, stygmaty te napotkać można wyłącznie u osób wykonujących cnoty w stopniu jak najbardziej heroicznym, i mających w szczególności wielką miłość krzyża ${ }^{54}$.

S. Urbański, powołując się na opinie polskich teologów, podaje podstawowy warunek uznania nadprzyrodzonego charakteru znaków ran stygmatycznych, odnoszący się bezpośrednio do osoby stygmatyka. Należy zbadać, czy stygmatyk praktykuje cnoty życia chrześcijańskiego w stopniu heroicznym. Następnie, czy odznacza się miłością do Chrystusa Ukrzyżowanego. Również trzeba zweryfikować autentyczność doznawanych innych łask mistycznych, wśród nich stany ekstatyczne i jaki mają one wpływ na jego życie. Zdaniem S. Urbańskiego, mistyka winien przepełniać wewnętrzny pokój wypływający z głębokiego zjednoczenie z Bogiem, cechować „powaga, równowaga zmysłowa i duchowa, jasność umysłu, a także logiczne myślenie mimo odczuwanego cierpienia" ${ }^{55}$. Nie jest to łatwe, ponieważ ,prawdziwe stygmaty są (...) często niezmiernie bolesne ${ }^{56}$. Powinno się również „usunąć wszystkie naukowe wątpliwości w porządku przyrodzonym"57. W dalszym etapie prowadzonych badań należy pamiętać, że stygmaty „pojawiają się (...) wyłącznie w miejscach, w których były rany Zbawiciela. Rany krwawią bardzo często ponad naturalną miarę i w takiż sposób, czego nie da się zaobserwować w sztucznie wywołanej stygmatyzacji Nie goją się one wcale. Utrzymując się nieraz bardzo długo, tzn. kilka lub nawet kilkanaście lat. Zazwyczaj otwierają się one regularnie w stałych dniach lub o stałej godzinie, kiedy [Pan] Jezus cierpiał swoją mękę albo kiedy jest obchodzone wspomnienie Męki Pańskiej" ${ }^{58}$.

P. M. Marianeschi proponuje przy ocenie autentyczności stygmatów uwzględnić następujące kryterium: „,brak zapalenia wokół ran oraz brak infekcji, krwawienie okresowe chroniczne, niezależne od czasów i praw normalnego krzepnięcia, trwanie nawet przez dziesiątki lat ze znakami świeżej rany, zniknięcie bez pozostawienia blizny, brak nekrozy (martwej tkanki), normalność zachowania fizjopatologicznego innych ran sprowokowanych chirurgicznie na tym samym ciele stygmatyka, które wywołują stan zapalny, ropieją, krzepną i zabliźniają jak każda inna rana, w przeciwieństwie do samoistnych stygmatów obecnych jednocześnie na tym samym ciele, zniknięcie bez blizny krwawiącej rany, to znaczy sięgającej głębiej niż warstwa naskórka"s9.

Zdaniem P. M. Marianeschi'ego, w oparciu o zebrane dokumenty historyczne, stwierdza się, że począwszy od czasów św. Franciszka z Asyżu, do początku XXI,

\footnotetext{
54 A. Tanquerey, Zarys teologii..., dz. cyt., s. 529 ns.

55 S. Urbański, Nadzwyczajne zjawiska..., dz. cyt., s. 357.

56 S. Urbański, Nadzwyczajne zjawiska..., dz. cyt., s. 357.

57 S. Urbański, Nadzwyczajne zjawiska..., dz. cyt., s. 357.

58 S. Urbański, Nadzwyczajne zjawiska..., dz. cyt., s. 357.

59 P. M. Marianeschi, Stygmaty..., dz. cyt., s. 122 ns.
} 
Kościół cieszył się ponad 500 stygmatykami, spośród nich około 100 żyło w XX w. Wśród nich - św. Ojciec Pio z Pietrelciny ${ }^{60}$, który zdaniem I. Burchackiej ,jest jedynym kapłanem - stygmatykiem" $"$.

A. Tanquerey, podejmując zagadnienie fenomenu stygmatyzacji, przypomniał, że pierwszym stygmatykiem był św. Franciszek z Asyżu, któremu 17 września 1224 r., w chwili nadzwyczajnej ekstazy, Zbawiciel udzielił charyzmatu widzialnych Swoich Ran. Rany te zachowały się aż do jego śmierci, która nastąpiła dwa lata później 11 października $1226 \mathrm{r}$. Wtedy też do wiadomości publicznej dotarła wieść o jego stygmatach $^{62}$.

R. Di Muro, chcąc wskazać okoliczności jego stygmatyzacji, przywołuje opis sporządzony przez Św. Bonawenturę z Bagnoregio. Z jego zeznania wynika, że „któregoś ranka, około święta Podwyższenia Krzyża Świętego"63, podczas porannej modlitwy Franciszek zobaczył na zboczu góry La Verna postać zstępującego z nieba serafina, mającego trzy pary ognistych i błyszczących skrzydeł, który zawisł przed nim w powietrzu. W tej samej chwili „pomiędzy skrzydłami ukazała się podobizna ukrzyżowanego człowieka, mającego ręce i nogi rozciągnięte na podobieństwo krzyża i do niego przybite. Dwa skrzydła wznosiły się ponad jego głową, dwa były rozciągnięte do lotu, a dwa okrywały całe ciało"64. Brat Franciszek rozpoznał w ukrzyżowanej postaci Chrystusa. Jezus udzielił mu łaski mistycznego przybicia do krzyża, a miecz solidarnego bólu przeszył jego duszę. Franciszek poznał, że przez „przez żar duszy może być zupełnie przemieniony na podobieństwo Ukrzyżowanego" ${ }^{\prime 65}$. W tej samej chwili ,znikająca wizja nie tylko rozpaliła przedziwny żar w jego sercu, ale i na jego ciele wycisnęła podobiznę nie mniej dziwnych znaków. Natychmiast zaczęły się pokazywać na jego rękach i nogach ślady gwoździ, jakie niedawno widział na podobiźnie ukrzyżowanego człowieka. Okazało się bowiem, że ręce i nogi zostały w środku przebite gwoźdźmi tak, że główki gwoździ było widać na wewnętrznej stronie rąk i na górnej stóp, zaś ich ostre końce na stronach przeciwnych. Główki gwoździ w rękach i nogach były okrągłe i czarne, a ich wydłużone ostre końce, zagięte i jakby powtórnie wbite, wystając z ciała, unosiły się nad jego pozostałą częścią. Również prawy bok był jakby włócznią przebity, a krew wypływająca często z ran plamiła habit i spodnie" ${ }^{\prime 6}$.

700 lat później, 23 września 1918 r., w kapucyńskim klasztorze w San Giovanni Rotondo, duchowy syn św. Franciszka - Ojciec Pio z Pietrelciny odprawiał w kościelnym chórze po Mszy Świętej dziękczynienie. Podczas modlitwy Zba-

60 P. M. Marianeschi, Stygmaty..., dz. cyt., s. 121.

${ }^{61}$ I. Burchacka, Ojciec Pio..., dz. cyt., s. 13.

62 A. Tanquerey, Zarys teologii..., dz. cyt., s. 529 ns.

${ }^{63}$ R. Di Muro, Franciszek z Asyżu. Typowi przedstawiciele mistyki chrześcijańskiej, w: Chrześcijańskie fenomeny mistyczne. Stownik, Kielce 2018, s. 161.

64 R. Di Muro, Franciszek z Asyżu..., dz. cyt., s. 161.

65 R. Di Muro, Franciszek z Asyżu..., dz. cyt., s. 161.

${ }^{66}$ R. Di Muro, Franciszek z Asyżu..., dz. cyt., s. 161. 
wiciel włączył go do elitarnego grona stygmatyków ${ }^{67}$. L. Peroni, badając okoliczności stygmatyzacji Kapucyna z Pietrelciny, odwołuje się do jego zeznania, które osobiście złożył w liście adresowanym do ojca duchownego (o. Benedetto), z datą 22 października 1918 r. Stygmatyk oświadczył: „Na chórze, po odprawieniu Mszy Świętej (nagle) ogarnął mnie stan spoczynku, podobny do słodkiego snu. Wszystkie zmysły, wewnętrzne i zewnętrzne, jak również wszystkie zmysły duszy zatopiły się w niewysłowionym spokoju. Otaczała mnie całkowita cisza, która ogarnęła także moje wnętrze. Pojawił się pełny spokój i aprobata dla całkowitego wyrzeczenia się wszystkiego oraz wytchnienie od boleści. Wszystko to wydarzyło się w okamgnieniu. I podczas gdy wszystko to się działo, ujrzałem przed sobą tajemniczą postać podobną do tej widzianej wieczorem 5 sierpnia [1918 - transwerberacja]. A różniąca się tym tylko, że jej ręce, nogi i bok ociekały krwią. Ten widok mnie przeraził, nie potrafię opisać, co czułem w tamtej chwili. Czułem, że umieram i zapewne umarkbym, gdyby Pan nie pospieszył mi z pomocą i nie podtrzymywał mego wyrywającego się z piersi serca. Wtedy tajemnicza postać znikła, a ja zobaczyłem, że moje ręce i nogi i bok zostały przebite i ociekają krwią..." ${ }^{68}$.

Włoski watykanista Francesco Castello odkrył drugie osobiste zeznanie św. Ojca Pio na temat przebiegu jego stygmatyzacji. Z jego badań wynika, że w dniach od 14 do 20 czerwca 1921 r., w kapucyńskim klasztorze w San Giovanni Rotondo przebywał wizytator watykański bp Carlo Rossi ${ }^{69}$. Ojciec Pio był przez niego przesłuchiwany pięciokrotnie ${ }^{70}$. Podczas pierwszego przesłuchania, które dnia 15 czerwca rozpoczęło się o godz. 17-tej, bp Rossi zwrócił się do niego w słowach: „proszę zeznać wyłącznie na okoliczność tak zwanych „stygmatów”71. Następnie osobiście spisał udzieloną przez Ojca Pio odpowiedź, który oświadczył co następuje, że: „20 września 1918 roku po odprawieniu Mszy, gdy zatrzymałem się w chórze na stosowne dziękczynienie, odstałem nagle wielkich dreszczy po całym ciele. Potem nastał spokój i zobaczyłem N.[aszego] P. [ana] w postawie jak na krzyżu, choć miałem wrażenie, że nie było krzyża, skarżącego się na brak wzajemności u ludzi, szczególnie u tych, którzy Mu się poświęcili i przez Niego są szczególnie umiłowani. Widać było, że cierpi i chce, by dusze ludzkie dzieliły z Nim Jego cierpienie. Zapraszał mnie, abym przejął się Jego cierpieniem i medytował nad nim, a jednocześnie troszczył się o zbawienie braci. Na te słowa poczułem się przepełniony współczuciem dla cierpiącego Pana i zapytałem Go, co mógłbym zrobić. Usłyszałem głos: „Weź udział w mojej Męce”. Po tych słowach, gdy wizja się skończyła, wszedłem w głąb siebie i rozpamiętywałem to, co się wydarzyło. Wtedy zobaczyłem te znaki, z których kapały krople krwi. Przedtem

${ }^{67}$ I. Burchacka, Ojciec Pio..., dz. cyt., s. 15.

68 L. Perroni, Ojciec Pio..., dz. cyt., s. 287.

${ }^{69}$ F. Castelli, Przesłuchanie Ojca Pio. Odtajnione archiwa Watykanu, Kraków 2019, s. 41-62.

70 F. Castelli, Przestuchanie Ojca Pio..., dz. cyt., s. 261.

71 F. Castelli, Przestuchanie Ojca Pio..., dz. cyt., s. 230. 
nic takiego nie miałem"72. Jak wynika z notatek wizytatora, dwa dni później, 17 czerwca 1921 r, o godz. 16.30 przybył on do celi Ojca Pio i w obecności miejscowego gwardiana o. Lorenzo przeprowadził osobiście drobiazgową weryfikację znaków stygmatycznych obu dłoni, stóp i boku ${ }^{73}$. Na jego prośbę stygmatyk zdjął „wełniane pół-rękawiczki”" ${ }^{74}$. Najpierw C. Rossi zbadał stygmat prawej dłoni. Na jej wewnętrznej stronie zobaczył rozległą okrągłą plamę o średnicy $5 \mathrm{~cm}$, pokrytą małymi strupkami, o brzegach w znacznej części uniesionych i z tego powodu wykazujących tendencję do odpadnięcia ${ }^{75}$. Na jej grzbiecie w części centralnej również stwierdził obecność podobnej okrągłej plamy, nieco mniejszej, bo o średnicy $3,5 \mathrm{~cm}$, pokrytej strupkami o brzegach bardziej uniesionych, które też zdawały się być bliskie odpadnięcia ${ }^{76}$. Biskup stwierdził, że środek plamy dolnej pokrywa się w linii prostej ze środkiem plamy górnej ${ }^{77}$. W drugiej kolejności zbadał stygmat prawej dłoni. Plama dolna miała średnicę $5 \mathrm{~cm}$, a górna $4 \mathrm{~cm}$. Wyniki były tożsame jak w dłoni lewej ${ }^{78}$. Po odkryciu obu stóp, biskup stwierdził, że są w stanie podobnym do ran znajdujących się na dłoniach ${ }^{79}$. Na koniec poddano badaniu ranę, która w swym kształcie przypominała trójkąt równoboczny, o długości boku $2 \mathrm{~cm}^{80}$. Badany, zapytany, czy te rany zadają mu ból - odpowiedział, że tak. Przy czym opisując ból w dłoniach wyznał: „Pobolewa mnie cała ręka, ostrzejszy ból pochodzi ze środka dłoni, od wewnątrz" ${ }^{\text {" }}$. Zapytany, czy może swobodnie się poruszać, odpowiedział: „Nie zawsze jest to jednakowo męczące. Na nogach mogę ustać niedługo z powodu wewnętrznego bólu" "82. F. Castelli przebadał również raport bpa Rossi'ego, wizytatora apostolskiego, który na piśmie złożył w styczniu 1922 r. na Watykanie ${ }^{83}$. Badacz archiwów watykańskich zwraca szczególną uwagę na jego definitywne stwierdzenie, że Ojciec Pio otrzymał stygmaty ${ }^{84}$. Bp C. Rossi oświadczył: „Stygmaty są. Stoimy przed faktem i trudno go kwestionować” ${ }^{85}$. W swoim raporcie przypomniał również słowa, które pod przysięgą wypowiedział stygmatyk, że „nigdy w sztuczny sposób nie powodował ani nie wspomagał stygmatów"86.

72 F. Castelli, Przestuchanie Ojca Pio..., dz. cyt., s. 230.

73 F. Castelli, Przestuchanie Ojca Pio..., dz. cyt., s. 243-248.

74 F. Castelli, Przestuchanie Ojca Pio..., dz. cyt., s. 243.

75 F. Castelli, Przestuchanie Ojca Pio..., dz. cyt., s. 243.

76 F. Castelli, Przestuchanie Ojca Pio..., dz. cyt., s. 244.

77 F. Castelli, Przestuchanie Ojca Pio..., dz. cyt., s. 245.

78 F. Castelli, Przestuchanie Ojca Pio..., dz. cyt., s. 245.

79 F. Castelli, Przestuchanie Ojca Pio..., dz. cyt., s. 245 ns.

80 F. Castelli, Przestuchanie Ojca Pio..., dz. cyt., s. 247.

81 F. Castelli, Przestuchanie Ojca Pio..., dz. cyt., s. 244.

82 F. Castelli, Przestuchanie Ojca Pio..., dz. cyt., s. 247.

83 F. Castelli, Przestuchanie Ojca Pio..., dz. cyt., s. 103-161.

${ }^{84}$ F. Castelli, Przestuchanie Ojca Pio..., dz. cyt., s. 56.

85 F. Castelli, Przestuchanie Ojca Pio..., dz. cyt., s. 132.

${ }^{86}$ F. Castelli, Przestuchanie Ojca Pio..., dz. cyt., s. 142. 


\section{Mistyczne ukoronowanie cierniem}

Wśród świętych Kościoła, stwierdził R. Di Muro, są mistycy, którym Bóg udzielił nadprzyrodzonej łaski doświadczenia duchowo lub fizycznie tortury ukoronowania cierniem Chrystusa ${ }^{87}$. Jego zdaniem ,fenomen ten polega na pojawieniu się na głowie osoby, ran podobnych do tych, jakiej powodowała korona cierniowa na skroniach Zbawiciela"88 (por. Mt 27,29; Mk 15,17; J 19,2-3), a z otwartych ran sączy się krew. Di Muro stwierdza, że „fenomen ten może zachodzić razem z widzeniami, które mają na celu wyjaśnienie głębokiego sensu cierpień Jezusa Chrystusa, oraz z objawami ekstatycznymi" "99. Faktem jest, że ten fenomen najczęściej zdarza się wśród kobiet, co znajduje potwierdzenie w każdym okresie historycznym. Di Muro wskazuje na św. Katarzynę Emmerich i św. Gemmę Galgani.

\section{Pocenie się krwią (hemotodroza)}

Zdaniem Marianeschi'ego zjawisko hemotodrozy mieści się „,w zakresie ogólnej definicji stygmatów, rozumianych jako znak męki Jezusa z Nazaretu, w nawiązaniu do relacji św. Łukasza, z której wynika, że podczas modlitwy Chrystusa w Ogrodzie Oliwnym „Jego pot był jak gęste krople krwi, sączące się na ziemię” (Łk 22,44) ${ }^{90}$. Marianeschi wyjaśnił, że to „zjawisko polega zasadniczo na tym, że osoba ciesząca się dobrym zdrowiem, a przede $\mathrm{w}$ wszystkim nie mająca problemów z krzepnięciem krwi, nagle i samoistnie zaczyna wydzielać krwawą (pozornie) ciecz z porów skóry, zwłaszcza na twarzy" ${ }^{91}$. W niektórych przypadkach zjawisko to „łączy się z wydzielaniem krwawych łez, gdzie krew lub krwista ciecz zdają się wypływać z oczu i (lub) ze śluzówek, a następnie zalewają twarz, tak iż często sprawia wrażenie zakrwawionej maski" '92. Czasem opisywany krwawy pot wydziela aromatyczną wońn ${ }^{93}$. Zdaniem Marianeschi'ego medycyna nie zna wyjaśnienia zaistnienia omawianego mistycznego fenomenu. Stwierdził on również fakt występowania omawianego zjawiska u wielu osób. Byli wśród nich św. Ludgarda, bł. Krystyna ze Stommeln, Magdalen Morice, Maria Dominika Lazzeri, także bł. Helena z Montallo Uffogo ${ }^{94}$.

W aktach procesu kanonizacyjnego włoskiej mistyczki i stygmatyczki bł. Heleny Aiello (1895-1961), stwierdza Marianeschi, zebrano liczne zeznania świadków, którzy osobiście widzieli powtarzający się w jej przypadku fenomen wydzielania

${ }^{87}$ R. Di Muro, Ukoronowanie cierniem, w: Chrześcijańskie fenomeny mistyczne. Stownik, Kielce 2018, s. 134.

${ }^{88}$ R. Di Muro, Ukoronowanie cierniem..., dz. cyt., s. 134.

89 R. Di Muro, Ukoronowanie cierniem..., dz. cyt., s. 135.

${ }_{90}$ P. M. Marianeschi, Pocenie się krwia (hematodroza/hematohydrozja), w: Chrześcijańskie fenomeny mistyczne. Stownik, Kielce 2018, s. 80.

${ }^{91}$ P. M. Marianeschi, Pocenie się krwiq..., dz. cyt., s. 80.

92 P. M. Marianeschi, Pocenie się krwia..., dz. cyt., s. 80.

93 P. M. Marianeschi, Pocenie się krwia..., dz. cyt., s. 80.

${ }^{94}$ P. M. Marianeschi, Pocenie się krwia..., dz. cyt., s. 80. 
się z jej organizmu potu, przybierającego kolor czerwony. Gdy matka Helena znajdowała się w ekstazie, na jej twarzy ukazywała się ciecz, która, jak się wydawało wypływała ,z porów skórnych, z cebulek włosów oraz z oczu. Ciecz koloru ciemnoczerwonego najpierw zalewała całą twarz, a następnie poszewki poduszki, tak iż powstawała wielka plama krwi, na której opierała się głowa z włosami przesączonymi materiałem hemoglobinowym, który był wydzielany przez małe, punktowe rany na owłosionej skórze z głowy i na czole" ${ }^{95}$. Świadków zdarzenia zaskakiwał sposób wygasania fenomenu. Okazywało się, że „fenomen tak jak zaczynał się w sposób niedostrzegalny, tak nagle i niedostrzegalnie zaczynał znikać i całkowicie usuwać" 96 . Po jego ustąpieniu twarz mistyczki wysychała powracając do pierwotnego stanu. Wszelkie czerwone plany znikały także z materiałów ubrań czy pościeli ${ }^{97}$.

\section{Krwawe obrazy i napisy (hemografia)}

Jednym z wyjątkowo spektakularnych spośród zjawisk mistycznych jest fenomenem hemografii. Włoski teolog R. Talmelli wyjaśnia, że „fenomen ten polega na tym, że z czyjejś nie uszkodzonej bądź pokrytej ranami skóry, w różnych okolicznościach wypływają strużki i krople krwi" "98. Po dotknięciu nawet najmniejszej kropelki krwi dowolną tkaniną, pojawiają się na niej „obrazy o charakterze religijnym, bądź wizerunki symboli liturgicznych" "99. Zdaniem R. Talmelli'ego „utworzone w ten sposób znaki, zawsze wyraźne i trwałe, na ogół przedstawiają krzyże, Hostie, kielichy lub aniołów" ${ }^{100}$. Te mistyczne obrazy nigdy nie pojawiają się bezpośrednio na ciele mistyka, lecz na powierzchniach rzeczy, które miały kontakt z powierzchnią jego skóry. R. Talmelli wskazuje m.in. na chusteczki i prześcieradła ${ }^{101}$.

Przypadki zjawiska hemografii zostały stwierdzone u współczesnej włoskiej stygmatyczki, mistyczki Fortunaty Etolo, znanej jako „mama Natuzza”102. Zdaniem R. Armenti'ego „ludzko-duchowa droga Fortunaty charakteryzowała się w szczególny sposób mistycznym fenomenem hemografii, przez długi czas obserwowanym i badanym" 103 . Fortunata doświadczała tej łaski w ściśle określonych okolicznościach: „po Komunii Świętej w okresie Wielkiego Postu oraz w Wielki Piątek, kiedy z krwi wyciekającej z jej ciała i gromadzącej się nawet w bardzo małych kropelkach,

95 P. M. Marianeschi, Pocenie się krwiq..., dz. cyt., s. 82.

${ }_{96}$ P. M. Marianeschi, Pocenie się krwią..., dz. cyt., s. 82.

${ }_{97}$ P. M. Marianeschi, Pocenie się krwią..., dz. cyt., s. 82.

98 R. Talmelli, Krwawe obrazy i napis (hemografia), w: Chrześcijańskie fenomeny mistyczne. Stownik, Kielce 2018, s. 54.

99 R. Talmelli, Krwawe obrazy..., dz. cyt., s. 54.

${ }^{100}$ R. Talmelli, Krwawe obrazy..., dz. cyt., s. 54.

${ }^{101}$ R. Talmelli, Krwawe obrazy..., dz. cyt., s. 54.

${ }^{102}$ F. Armenti, Natuzza Etolo - „Robak z ziemi”, który stat się nasieniem”, w: Chrześcijańskie fenomeny mistyczne. Słownik, Kielce 2018, s. 189.

${ }^{103}$ F. Armenti, Natuzza Etolo..., dz. cyt., s. 194. 
na chusteczce lub szmatce pojawiały się w sposób tajemniczy i niewytłumaczalny różne napisy, także w nieznanych mistyczce obcych i starożytnych językach, po łacinie i po grecku, jak również święte wizerunki”'104. W jej przypadku stwierdzono, że zjawisko to towarzyszyło jej ponad 50 lat. $\mathrm{Z}$ opisów mistyczki, do których odwołują się badający przypadek Etolo wynika, że po raz pierwszy mistyczka doświadczyła opisywanego charyzmatu w 1939 r. Po przyjęciu Komunii Świętej, „z kropli krwi, która spłynęła po twarzy i którą wytarła chusteczką, utworzył się napis: „Chwała Najświętszemu Sercu Jezusa" ${ }^{105}$. Z badań przeprowadzony przez V. Marinellego wynika, że 19 czerwca 1940 r., Natuzza przyjęła w katedrze w Mileto sakrament bierzmowania. W chwili namaszczenia krzyżem, poczuła ból na plecach i stwierdziła, że ma mokrą koszulę. Gdy wróciła do miejsca zamieszkania, pani domu Alba Colloca zauważyła, że koszula była poplamiona krwią, oraz że ukazuje się na niej „krzyż wielkości odpowiadający plecom”"106.

Zachowały się opisy świadków, którzy na żywo uczestniczyli w pojawieniu się tego mistycznego fenomenu. A. Magro, korespondent prasowy z Neapolu, w $1948 \mathrm{r}$. przybył do Paravati, aby spotkać się z mistyczką. Podczas rozmowy „,nagle zaczyna dawać znaki, jakby się źle czuła (...) i poci się krwią. (...) Ktoś wyjął z kieszeni chusteczkę (...) i wytarł jej czoło..." ${ }^{107}$. Świadkowie stwierdzili, że ukazał się rysunek z krwi. U góry był kielich, z tego kielicha wychodziła jakaś droga, która prowadziła w dół i skręcała; na początku zakrętu było dwóch aniołów, a poniżej, na końcu drogi, widniał napis po łacinie: Deus in terra vissus est" ${ }^{\prime 108}$. Kierownik duchowy Natuzzy, ks. G. Tomaselli zaświadczył: „Kiedy udzielałem jej Komunii Świętej, zauważyłem, że miała dość mocno zakrwawione oko. Zawołałem ją do zakrystii, prosząc, by podać tej pani do otarcia puryfikaterz, ale zakrystianin był starszym człowiekiem i bardzo powolnym. Wtedy ona zauważyła, że krwawi, więc wytarła sobie krew własną chusteczką, na której ukazała się monstrancja z napisami IHS i CI oraz VENITE AD $M E O M N E S^{\prime \prime 109}$. Znajoma Fortunaty, Carmena z Vibo złożyła oświadczenie, z którego wynika, że w 1990 r., w drugi piątek Wielkiego Postu odwiozła mistyczkę na poranną Mszę Świętą do Parvazzi. Gdy podczas modlitwy „Ojcze nasz” podniosła ona ręce, na grzbiecie lewej ręki ukazała się plamka krwi. Stojąc po lewej stronie mistyczki, wytarła plamkę własną chusteczką i schowała do kieszeni kurtki. Miesiąc później, gdy rozłożyła chusteczkę zobaczyła obraz: widoczna była Hostia z napisem IHS w środku, krzyżem, koroną cierniową, sercem z górującym nad nim krzyże. Na koniec stwierdziła: „Wytarłam zaledwie malutką plamkę, ponieważ wyglądała jak niewielkie zadraśnięcie"110.

\footnotetext{
${ }^{104}$ F. Armenti, Natuzza Etolo..., dz. cyt., s. 194.

${ }^{105}$ F. Armenti, Natuzza Etolo..., dz. cyt., s. 195.

${ }^{106}$ F. Armenti, Natuzza Etolo..., dz. cyt., s. 194.

${ }^{107}$ F. Armenti, Natuzza Etolo..., dz. cyt., s. 195.

${ }^{108}$ F. Armenti, Natuzza Etolo..., dz. cyt., s. 195.

${ }^{109}$ F. Armenti, Natuzza Etolo..., dz. cyt., s. 195.

${ }^{110}$ F. Armenti, Natuzza Etolo..., dz. cyt., s. 195.
} 


\section{Zakończenie}

Tajemnica Męki, śmierci i Zmartwychwstania Jezusa Chrystusa, przez którą dokonuje się nasze zbawienie, jest najbardziej wiarygodnym świadectwem, że Bóg jest bogaty w Miłosierdzie ${ }^{111}$. Wydarzenia paschalne wciąż inspirują pobożność wiernych. Również Bóg rozpala w duszach wiernych, umiłowanie Pasji Jezusa Chrystusa, udzielając wybranym przez Siebie mistykom charyzmatów bezpośrednio związanych z Jego Męką i Zmartwychwstaniem.

Celem artykułu było ukazanie mistycznych fenomenów, poprzez które Bóg w osobach wybranych przez Siebie wiernych, począwszy od czasów apostolskich, kieruje serca wiernych ku Tajemnicy Zbawienia. Ponadto, przywołano udokumentowane przykłady mistyków Kościoła, naznaczonych niewidzialnie lub widzialnie znakami Ran Syna Bożego.

Żywa księga życia mistyków Kościoła, w której Bóg wpisał prawdę o Zbawczej Ofierze Swojego Syna, wydaje się być w świetle przeprowadzonych badań, podstawą niezachwianej wiary w Miłosierdzie Boże. Z przeprowadzanych badań wynika, iż najsłynniejszym mistykiem pasyjnym był św. Ojciec Pio z Pietrelciny. Godnym zauważanie jest fakt, że wśród mistyków pasyjnych uznanych przez Kościół za wiarygodnych świadków w akcie ich wyniesienia na ołtarze, ważne miejsce zajmuje polska mistyczka św. Siostra Faustyna Kowalska. Z treści artykułu wynika również fakt pojawienia się na gruncie mistyki polskiej, pism Alicji Lenczewskiej. I choć już zostały one uznane za perłę literatury religijnej ${ }^{112}$, winny stać się przedmiotem dalszych badań ${ }^{113}$.

\section{BIBLIOGRAFIA}

\section{Źródła drukowane:}

Jan Paweł II, Encyklika „Divus In misericordia”, Watykan 1980.

Kowalska F., Dzienniczek, Kraków 2012.

\section{Opracowania:}

Burchacka I., Ojciec Pio. Osobowość i postuga w relacjach wspótczesnych, Warszawa 1988.

111 Jan Paweł II, Encyklika „Divus In misericordia”, Watykan 1980.

${ }_{112}$ M. Piątkowski, Świadek Zmartwychwstałego..., dz. cyt., s. 9.

${ }^{113}$ Przykładem zaskakującego objawienia tłumaczącego przyczynę śmierci Chrystusa, są Jego słowa skierowane do A. Lenczewskiej 20 listopada 1987 r. Jezus zapytał wówczas polską mistyczkę: „Czy wiesz, dlaczego umarłem na Krzyżu?” i udzielił zaskakującej odpowiedzi: „Serce Moje pękło, bo spotkało się w nim całe zło świata i nieskończone Miłosierdzie Boże. A ponieważ zło jest skończone, Miłość zwyciężyła w Zmartwychwstaniu. I ogarnia świat Duchem Świętym”. A. Lenczewska, Świadectwo..., dz. cyt., s. 510. 
Castelli F., Przestuchanie Ojca Pio. Odtajnione archiwa Watykanu, Kraków 2008. Chrześcijańskiefenomeny mistyczne. Stownik, opr. L. Borriello, R. Di Muro, Kielce 2018. Garrigou-Lagrange R., Trzy okresy życia wewnętrznego, Niepokalanów 2001.

Gogola J., Fenomeny doświadczeń mistycznych, w: Encyklopedia Katolicka KUL, t. 12, Lublin 2008.

Lenczewska A., Świadectwo, Poznań 2016.

Lenczewska A., Stowo Pouczenia, Poznań 2016.

Peroni L., Ojciec Pio. Petna biografia w 40. rocznice śmierci, t. 2, Kraków 2008.

Rachwalik W., Pisma Alicji Lenczewskiej jako przykład literatury z zakresu mistyki, „Świdnickie Studia Teologiczne” 15 (2018) nr 1, s. 145-159.

Rebeta W., Misterium cierpienia świętej Faustyny, Lublin 2014.

Tanquerey A., Zarys teologii ascetycznej i mistycznej, t. 2, Warszawa 2003.

Turowski K., Oblubienica Boga. Rozmowa z ks. Walterem Rahwalikiem ojcem duchownym Alicji Lenczewskiej, Kraków 2019.

Urbański S., Teologia życia mistycznego, Warszawa 1999.

Witek S., Teologia życia wewnętrznego, Lublin 1986.

\section{Streszczenie:}

W doświadczeniach mistyków Kościoła ważne miejsce zajmuje fakt ich partycypacji w Męce Jezusa Chrystusa. Mistycy mogą otrzymać dary niewidzialnego przebicia serca i niewidzialnych stygmatów, również widzialnego udziału w biczowaniu, w ukoronowaniu cierniem i w ukrzyżowaniu Zbawiciela, co przyjmuje formę faktycznego przebicia ich dłoni, stóp i serca. Dopełnieniem są zjawiska krwawego potu i krwawych obrazów i napisów. Tak więc fenomeny pasyjne im udzielone są rzeczywistym odbiciem tajemnic Golgoty. Ich życie, przybiera formę żywej księgi pamięci o cenie Zbawienia, którą Jezus Chrystus zapłacił na drzewie Krzyża.

Slowa klucze: mistyka Golgoty, fenomeny mistyczne, męka Jezusa Chrystusa

\section{The Mystical Phenomena of the Passion}

\section{Summary}

An important place in the experiences of the mystics of the Church is the fact of their participation in the Passion of Jesus Christ. Mystics can receive the gifts of an invisible puncture of the heart and invisible stigmata, also of a visible participation in whipping, crowning with thorns and the crucifixion of the Savior, which takes the form of the actual piercing of their hands, feet and heart. Complementing the phenomena is bloody sweat, bloody images and inscriptions. Thus, the passion phe- 
nomena given to them are a real reflection of the secrets of Golgotha. Their life takes the form of a living book of remembrance about the price of Salvation, which Jesus Christ paid on the wood of the Cross.

Key words: Golgotha mysticism, mystical phenomena, passion of Jesus Christ 